\title{
HUBUNGAN KENAKALAN REMAJA DENGAN FUNGSI SOSIAL KELURGA DI DESA MEKAR JAYA
}

\author{
At Prayer \\ Fakultas IImu Sosial dan IImu Politik Universitas PGRI Palangka Raya \\ (email: atprayer88@gmail.com)
}

\begin{abstract}
Abstrak
Penelitian ini bertujuan untuk: (1) Untuk mendeskripsikan bentuk-bentuk kenakalan dilakukan remaja di Desa Mekar Jaya. (2) Untuk mendeskripsikan hubungan kenakalan remaja dengan fungsi sosial keluarga di Desa Mekar Jaya.

Jenis penelitian dalam skripsi ini adalah penelitian lapangan (field research), karena pengambilan sumber datanya di lapangan-dalam hal ini data kasus-kasus kenakalan remaja yang terjadi di Desa Mekar Jaya untuk kemudian dideskripsikan dan dianalisis sehingga dapat menjawab persoalan yang telah dirumuskan dalam pokok masalah.

Hasil penelitian ini dapat disimpulkan : Bahwa bentuk-bentuk kenakalan remaja Mekar Jaya sebagaimana yang telah disebutkan dalam konsep teori, yaitu terdapat tiga bentuk kenakalan: a) Kenakalan biasa, seperti berbohong, begadang, pergi keluar rumah tanpa pamit, keluyuran, membolos sekolah, berkelahi dengan teman dan sebagainya; b) kenakalan yang menjurus pada pelanggaran dan kejahatan, seperti mengendarai kendaraan bermotor tanpa SIM, kebut-kebutan/ mengebut, minum-minuman keras, mencuri, mencopet, berjudi dan menodong; dan c) kenakalan khusus, seperti menyalahgunakan narkotika, kumpul kebo, hubungan sex di luar nikah, menggugurkan kandungan, memperkosa, membunuh, melihat, membaca dan menonton gambar-gambar porno dan sebagainya. Berdasarkan hasil wawancara dan analisis yang telah dilakukan dapat diketahui bahwa ada hubungan negatif antara keberfungsian sosial keluargannya dengan kenakalan remaja di Mekar Jaya Kecamatan Parenggean. Identitas remaja, baik sebagai pelajar ataupun pekerja samasama mempunyai kesempatan untuk melakukan kenakalan, baik itu kenakalan biasa, kenakalan khusus maupun kenakalan yang menjurus pada pelanggaran dan kejahatan. Remaja yang memiliki waktu luang banyak seperti mereka yang tidak bekerja atau menganggur dan masih pelajar kemungkinannya lebih besar untuk melakukan kenakalan atau perilaku menyimpang. Demikian juga dengan keberfungsian sosial keluarga, bahwa keluarga yang nota bene-nya keluarga yang utuh pun tidak menjamin anak untuk tidak melakukan kenakalan, terlebih lagi keluarga yang tingkat keberfungsian sosialnya rendah, maka kemungkinan besar anaknya akan melakukan kenakalan pada tingkat yang lebih berat.
\end{abstract}

Kata kunci : Kenakalan Remaja, Fungsi Sosial Keluarga

\section{Jurnal Sociopolitico}




\section{Pendahuluan}

Dalam kehidupan ini, manusia sejak awal hingga sekarang, selalu mengalami perubahan-perubahan, baik pada fisik jasmaniah, maupun mentalnya, baik perubahan negatif maupun positif. Perubahan-perubahan tersebut tidak lain merupakan hasil dari karya, cipta, dan karsa manusia yang selalu berkembang dan berjalan seiring dengan bergulirnya waktu.

Perubahan perilaku yang bersifat negatif dari masyarakat sebagai dampak dari pembangunan dapat dilihat antara lain dengan gaya hidup yang glamour, pergaulan bebas, hedonistik yang semuanya diekspresikan sesuai dengan tingkat intelektualitas dan kelas sosialnya masing-masing. Remaja misalnya, yang merupakan bagian dari masyarakat adalah komunitas yang paling rentan dalam menerima perubahan-perubahan tersebut. Karena pada masa itu adalah masa memasuki fase pencarian jati diri. Dalam pencarian jati dirinya mereka mengekspresikannya dengan berbagai cara dan gaya, selalu ingin tampil beda dan menarik perhatian orang lain. Dalam fase ini jika tidak diimbangi dengan kokohnya benteng moral dan agama, maka sudah pasti bisa diduga arah jalan kehidupannya.

Demikian halnya, bahwa peran dan tanggungjawab semua komponen bangsa dibutuhkan sebagai perwujudan kepetdulian dan tindakan pencegahan terhadap semua itu. Keluarga sebagai lingkungan masyarakat terkecil merupakan modal dasar bagi orang tua untuk memberikan bimbingan dan pengarahan moral dan pendidikan agama terhadap anak-anaknya dalam menghadapi masa (perkembangan dan pertumbuhan) remaja dan perubahan-perubahan yang terjadi di lingkungannya.

Jaman sekarang, sering kali didengar banyak remaja-remaja yang terlibat dalam kenakalan remaja, seperti perkelahian, narkoba, sex bebas sampai masalah paling parah, seperti tindakan kriminal. Namun, pernahkah disadari bahwa kenakalan yang ditimbulkan oleh para remaja, selain adalah tanggung jawab dari remaja itu sendiri, juga merupakan tanggung jawab orang-orang dan lingkungan di sekitar mereka?

Banyak faktor yang menjadi pencetus dari kenakalan remaja. Salah satu yang akan dibahas ini adalah kenakalan remaja yang berkaitan dengan keluarga. Keluarga merupakan sosialisasi manusia yang terjadi pertama kali sejak lahir hingga perkembangannya menjadi dewasa. Itulah sebabnya sebelum berlanjut kepada kenakalan remaja yang disebabkan oleh faktor yang lebih banyak lagi, maka akan lebih baik mulai memperhatikan dari permasalahan yang paling mendasar yaitu keluarga.

William J. Goode, mengartikan keluarga sebagai suatu satuan sosial terkecil yang dimiliki manusia sebagai makhluk sosial yang ditandai adanya kerjasama ekonomi. Fungsi keluarga adalah berkembang biak, mensosialisasi atau mendidik anak, menolong, melindungi dan sebagainya. Keluarga dapat dibagi menjadi bermacam-macam, seperti keluarga inti, keluarga besar, dan lain-lain. Tetapi dalam kenyataan, lebih sering keluarga dideskripsikan dengan gambaran keluarga inti yaitu keluarga yang terdiri dari ayah, ibu, dan saudara kandung. Secara idealnya, keluarga adalah ayah dan ibu yang bersatu dan bahu membahu dalam mendidik dan 
membimbing anaknya dalam masa pertumbuhan dan perkembangan. Ayah dan ibu adalah panutan anak sejak kecil hingga remaja dan hal tersebut akan berlangsung terus menerus sampai mereka memiliki anak lagi dan berlanjut terus seperti ini. Peran keluarga sangat penting bagi sosialisasi anak di masa perkembangannya.

Berdasarkan asumsi tersebut, maka keluarga (baca: orang tua) memiliki peran yang signifikan dalam menciptakan individu-individu dengan berbagai macam bentuk kepribadiannya dalam masyarakat. Selain itu, menurut Kumanto Sunarto dalam bukunya Pengantar Sosiologi bahwa keluarga pada umumnya berfungsi sebagai; pertama, peran reproduksi yaitu sebagai pengembangan keturunan; kedua, peran afeksi yaitu dengan jalan memberikan pengasuhan dan cinta kasih terhadap anak; ketiga, peran penentuan status sosial pada anak dalam kelas sosial tertentu seperti status sosial yang diperoleh oleh orang tuanya; keempat, sebagai pelindung bagi individu-individu yang menjadi anggotanya. Perlindungan tersebut dapat terwujud dengan terciptanya rasa aman dan tenteram (keteraturan sosial) dalam kehidupan suatu keluarga; kelima, menjalankan berbagai fungsi ekonomi dengan cara memenuhi kebutuhan-kebutuhan primer seperti makan, minum, tempat tinggal dan pakaian dan kebutuhan-kebutuhan skunder seperti kendaraan, televisi dan sebagainya; keenam, peran keagamaan yaitu memberikan pemahaman terhadap semua anggota keluarga untuk menjalankan ajaran agama yang mereka anut.

Kenakalan remaja dalam studi sosial dapat dikategorikan ke dalam perilaku menyimpang. Dalam perspektif perilaku menyimpang masalah sosial terjadi karena terdapat penyimpangan perilaku dari berbagai aturan-aturan sosial ataupun dari nilai dan norma sosial yang berlaku. Perilaku menyimpang dapat dianggap sebagi sumber masalah karena dapat membahayakan tegaknya sistem sosial.

Untuk mengetahui latar belakang perilaku menyimpang perlu membedakan adanya perilaku yang tidak disengaja dan yang disengaja, di antaranya karena si pelaku kurang memahami aturan-aturan yang ada. Sedangkan perilaku menyimpang yang disengaja, bukan karena si pelaku tidak mengetahui aturan. Hal yang relevan untuk memahami bentuk perilaku tersebut adalah mengapa seseorang melakukan penyimpangan, sedangkan ia mengetahui apa yang dilakukannya melanggar aturan. Becker yang dikutip Soerjono Soekanto dalam bukunya Sosiologi Suatu Pengantar mengatakan bahwa tidak ada alasan untuk mengasumsikan hanya mereka yang menyimpang mempunyai dorongan untuk berbuat demikian. Hal ini disebabkan karena pada dasarnya setiap manusia pasti mengalami dorongan untuk melanggar pada situasi tertentu, tetapi mengapa pada kebanyakan orang tidak menjadi kenyataan yang berwujud penyimpangan, sebab orang dianggap normal biasanya dapat memahami diri dari dorongandorongan untuk menyimpang.

Kemudian proses sosialisasi terjadi dalam kehidupan sehari-hari melalui interaksi sosial dengan menggunakan media atau lingkungan sosial tertentu. Oleh sebab itu, kondisi kehidupan lingkungan tersebut akan mewarnai dan mempengaruhi input dan pengetahuan yang diserap. Salah satu variasi yang menjelaskan kriminalitas di daerah perkotaan, bahwa beberapa tempat di kota

\section{Jurnal Sociopolitico}


mempunyai sifat yang kondusif bagi tindakan kriminalitas oleh karena lokasi tersebut memiliki karakteristik tertentu, misalnya Emile Durkheim mengatakan tingkat kriminalitas yang tinggi dalam masyarakat kota pada umumnya berada pada bagian wilayah kota yang miskin, dampak perumahan yang di bawah standar, overcrowding, derajat kesehatan yang rendah, serta komposisi penduduk yang tidak stabil.

Penelitian inipun dilakukan di daerah Desa Mekar Jaya tampak ciri-ciri seperti yang disebutkan Durkheim di atas. Seorang belajar untuk menjadi kriminal melalui interaksi. Apabila lingkungan interaksi cenderung devian, maka seseorang akan mempunyai kemungkinan besar untuk belajar tentang teknik dan nilai-nilai devian yang pada gilirannya akan memungkinkan untuk menumbuhkan tindakan kriminal.

\section{Metode Penelitian}

Jenis penelitian dalam skripsi ini adalah penelitian lapangan (field research), karena pengambilan sumber datanya di lapangan-dalam hal ini data kasus-kasus kenakalan remaja yang terjadi di Desa Mekar Jaya untuk kemudian dideskripsikan dan dianalisis sehingga dapat menjawab persoalan yang telah dirumuskan dalam pokok masalah.

\section{Hasil dan Pembahasan}

\section{Bentuk Kenakalan yang Dilakukan Remaja Desa Mekar Jaya}

Berdasarkan data di lapangan dapat disajikan hasil penelitian tentang kenakalan remaja sebagai salah satu perilaku menyimpang hubungannya dengan keberfungsian sosial keluarga, seperti yang terjadi di Desa Mekar Jaya.
Adapun ukuran yang digunakan untuk mengetahui kenakalan remaja seperti yang disebutkan dalam kerangka konsep terdahulu ada tiga, yaitu 1) Kenakalan biasa; 2) Kenakalan yang menjurus pada pelanggaran dan kejahatan; dan 3) Kenakalan Khusus.

Menurut hasil observasi dan wawancara dengan Bardiono dan Martoyo selaku tokoh masyarakat di Mekar Jaya, bahwa masalah bentuk-bentuk kenakalan atau penyimpangan yang dilakukan remaja Mekar Jaya, lebih banyak menjurus kepada kenakalan biasa, (seperti, berkelahi, membolos sekolah, tidak pamit pergi keluar rumah, terlibat minumminuman keras dan sebagainya. Namun, demikian, ada juga sebagian remaja yang melakukan kenakalan-kenalan yang menjurus pada pelanggaran atau tindak pidana. Namun, itu tidak seberapa jumlahnya.

Adapun bentuk-bentuk kenakalan yang dilakukan remaja di Desa Mekar Jaya Kecamatan Parenggean yang dapat diketahui sebagaimana dalam tabel berikut ini:

\section{Tabel 1}

Bentuk-Bentuk Kenakalan Remaja Parenggean

\begin{tabular}{|c|c|c|c|}
\hline No & Bentuk-Bentuk Kenakalan & $\mathbf{F}$ & $\%$ \\
\hline 1 & $\begin{array}{ll}\text { Kenakalan biasa: } \\
\text { a. } & \text { Berbohong } \\
\text { b. } & \text { Begadang } \\
\text { c. } & \text { Pergi keluar rumah } \\
& \text { tanpa pamit } \\
\text { d. } & \text { Keluyuran } \\
\text { e. } & \text { Membolos sekolah } \\
\text { f. } & \text { Berkelahi dengan teman } \\
\text { g. } & \text { Berkelahi antar sekolah } \\
\text { h. } & \text { Buang sampah } \\
& \text { sembarangan } \\
\end{array}$ & $\begin{array}{c}30 \\
26 \\
30 \\
28 \\
8 \\
13 \\
2 \\
19\end{array}$ & $\begin{array}{r}100 \\
98,7 \\
100 \\
93,3 \\
26,6 \\
43,3 \\
6,17 \\
63,3\end{array}$ \\
\hline \multicolumn{2}{|r|}{ Jumlah } & $\mathbf{N}=30$ & $100=(\%)$ \\
\hline 2 & $\begin{array}{l}\text { Kenakalan yang Menjurus } \\
\text { pelanggaran: } \\
\text { a. Mengendarai kendaraan } \\
\text { bermotor tanpa SIM } \\
\text { b. Kebut-kebutan/ } \\
\text { mengebut } \\
\text { c. Minum-minuman keras }\end{array}$ & $\begin{array}{c}15 \\
25 \\
9 \\
7 \\
8 \\
\end{array}$ & $\begin{array}{l}83,3 \\
\\
50,0 \\
83,3 \\
30,0 \\
23,3 \\
26,6 \\
\end{array}$ \\
\hline
\end{tabular}

\section{Jurnal Sociopolitico}




\begin{tabular}{|c|c|c|c|}
\hline & $\begin{array}{ll}\text { d. } & \text { Mencuri } \\
\text { e. } & \text { Mencopet } \\
\text { f. } & \text { Berjudi } \\
\text { g. } & \text { menodong }\end{array}$ & 2 & 6,6 \\
\hline \multicolumn{2}{|r|}{ Jumlah } & $\mathbf{N}=\mathbf{3 0}$ & $100=(\%)$ \\
\hline 3 & $\begin{array}{ll}\text { a. } & \text { Menyalahgunakan } \\
\text { narkotika } \\
\text { b. Kumpul kebo } \\
\text { c. Hubungan sex di luar } \\
\text { nikah } \\
\text { d. Menggugurkan } \\
\text { eandungan } \\
\text { f. Memperkosa } \\
\text { f. Membunuh } \\
\text { g. Melihat gambar porno } \\
\text { h. Membaca buku porno } \\
\text { i. Menonton film porno }\end{array}$ & $\begin{array}{c}11 \\
7 \\
17 \\
2 \\
1 \\
1 \\
15 \\
5 \\
10\end{array}$ & $\begin{array}{c}36,6 \\
23,3 \\
56,6 \\
6,7 \\
3,13 \\
3,13 \\
50,0 \\
16,17 \\
33,3\end{array}$ \\
\hline \multicolumn{2}{|r|}{ Jumlah } & $\mathrm{N}=30$ & $100=(\%)$ \\
\hline
\end{tabular}

Sumber: Data yang diolah

Berdasarkan tabel di atas, dapat dipahami bahwa bentuk-bentuk kenakalan remaja di Mekar Jaya, pada umumnya seluruh remaja pernah melakukan kenakalan, baik laki-laki maupun perempuan, terutama pada tingkat kenakalan biasa seperti berbohong, pergi ke luar rumah tanpa pamit pada orang tuanya, keluyuran, berkelahi dengan teman, membuang sampah sembarangan dan jenis kenakalan biasa lainnya.

Namun, meskipun demikian, pada tingkat kenakalan yang menjurus pada pelanggaran dan kejahatan seperti mengendarai kendaraan tanpa SIM, kebutkebutan, mencuri, menodong, mencopet, minum-minuman keras, berjudi, dan sebagainya juga cukup banyak dilakukan oleh remaja, terutama kenakalan mengendarai sepeda motor tanpa menggunakan SIM dan minum-minuman keras.

Sementara pada kenakalan khusus, meskipun kecil presentasenya, namun ada juga yang dilakukan oleh remaja seperti hubungan seks di luar nikah, menyalahgunakan narkotika, pembunuhan, pemerkosaan, menggugurkan kandungan bahkan ada juga yang berani 'kumpul kebo' atau satu rumah tanpa adanya hubungan nikah. Keadaan yang demikian cukup memprihatinkan. Kalau hal ini tidak segera ditanggulangi akan membahayakan baik bagi pelaku, keluarga maupun masyarakat. Karena dapat menimbulkan masalah sosial di kemudian hari yang semakin kompleks. Apalagi Mekar Jaya termasuk wilayah yang dapat dikatakan agamis.

Untuk mengetahui hubungan kenakalan remaja ini ada kaitannya dengan sistem keberfungsian sosial keluarga, berikut ini akan diuraikan, namun sebelumnya terlebih dahulu dibahas masalah hubungan antara identitas remaja dengan tingkat kenakalan, kemudian akan diuraikan hubungan keberfungsian sosial keluarga dengan kenakalan yang dilakukan remaja di Desa Mekar Jaya Kecamatan Parenggean.

\section{Hubungan antara Identitas Remaja dengan Tingkat Kenakalan}

\section{1) Hubungan antara jenis kelamin dengan tingkat kenakalan}

Salah satu pembahasan dalam tulisan ini adalah mengutarakan hubungan antara identitas remaja dengan tingkat kenakalannya yang disajikan dalam penelitian di sini adalah hubungan antara jenis kelamin dengan tingkat kenakalan. Hal ini untuk mengetahui apakah anak laki-laki lebih nakal dari anak perempuan atau kesempatannya sama, sebagaimana keterangan dalam tabel di bawah ini:

\section{Tabel 2}

Jumlah Jenis Kelamin dengan Tingkat Kenakalan

\begin{tabular}{|c|c|c|c|c|}
\hline No & $\begin{array}{c}\text { Jenis } \\
\text { Kelamin }\end{array}$ & Bentuk Kenakalan & $\mathbf{F}$ & $\%$ \\
\hline 1 & Laki-Laki & $\begin{array}{ll}\text { a. } & \text { Kenakalan Biasa } \\
\text { b. } & \text { Kenakalan } \\
& \text { Khusus } \\
\end{array}$ & $\begin{array}{c}4 \\
21 \\
2 \\
\end{array}$ & $\begin{array}{l}13,3 \\
70,0 \\
6,66 \\
\end{array}$ \\
\hline
\end{tabular}

\section{Jurnal Sociopolitico}




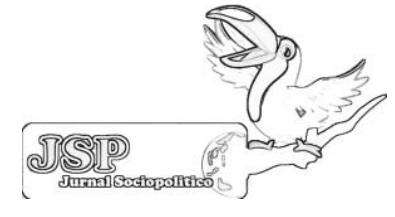

\begin{tabular}{|c|l|ll|c|c|}
\hline & & c. & $\begin{array}{l}\text { Menjurus } \\
\text { kepada } \\
\text { Pelanggaran }\end{array}$ & & \\
\hline 2 & Perempuan & a. & Kenakalan Biasa & 3 & 10,0 \\
& & b. & Kenakalan & 1 & 3.33 \\
& & Khusus & - & - \\
& & c. $\begin{array}{l}\text { Menjurus } \\
\text { kepada } \\
\text { Pelanggaran }\end{array}$ & & \\
\hline
\end{tabular}

Sumber: Data yang diolah

Berdasarkan data tabel di atas, bahwa hubungan yang diperoleh menunjukkan bahwa remaja yang melakukan kenakalan dominan dilakukan oleh remaja laki-laki, seperti kenakalan biasa yang melakukan tiga remaja atau $13,3 \%$ nya, kenakalan yang menjurus pada pelanggaran dan kejahatan ada dua remaja, dan kenakalan khusus ada 21 remaja atau sekitar 70,0\%. Sedangkan anak perempuan yang melakukan kenakalan biasa ada dua remaja atau sekitar $10,0 \%$ dan kenakalan khusus satu remaja atau 3,3\%-nya. Kenyataan tersebut menunjukkan bahwa sebagian besar yang melakukan kenakalan khusus adalah anak laki-laki atau 70,0\%nya, namun demikian terdapat juga anak perempuan yang melakukannya.

Kalau dibandingkan di antara 27 remaja anak laki-laki yang menjadi responden, 22 remaja atau $80,0 \%$ di antaranya melakukan kenakalan khusus, sedangkan dari tiga remaja perempuan hanya satu remaja atau $33,3 \%$ yang melakukan kenakalan khusus, berarti kesempatan anak laki-laki lebih besar kecenderungannya untuk melakukan kenakalan khusus. Demikian juga yang melakukan kenakalan yang menjurus pada pelanggaran dan kejahatan, anak perempuan tidak ada yang melakukannya. Dengan demikian, maka anak laki-laki kecenderungannya akan melakukan kenakalan yang menjurus pada pelanggaran dan kejahatan, lebih dibandingkan dengan anak perempuan.

\section{2) Hubungan antara pekerjaan dengan tingkat kenakalan yang dilakukan}

Berdasarkan data yang ada, remaja yang bekerja, juga dapat mempengaruhi kenakalan remaja, baik pekerjaannya sebagai pelajar, pedagang ataupun memang dia pengangguran dan sebagainya. Untuk lebih jelasnya berikut keterangan dalam tabel di bawah:

Tabel 3

Jumlah Remaja dalam Tingkat

Pekerjaan

\begin{tabular}{|c|c|c|c|c|c|}
\hline No & Pekerjaan & \multicolumn{2}{|c|}{ Bentuk Kenakalan } & $\mathbf{F}$ & $\%$ \\
\hline 1 & Pelajar & $\begin{array}{l}\text { 1) } \\
\text { 2) } \\
\text { 3) }\end{array}$ & $\begin{array}{l}\text { Kenakalan } \\
\text { Biasa } \\
\text { Kenakalan } \\
\text { Khusus } \\
\text { Menjurus } \\
\text { kepada } \\
\text { Pelanggaran }\end{array}$ & $\begin{array}{l}5 \\
2\end{array}$ & $\begin{array}{c}16,7 \\
6,7\end{array}$ \\
\hline 2 & Penganggur & 1) & $\begin{array}{l}\text { Kenakalan } \\
\text { Biasa } \\
\text { Kenakalan } \\
\text { Khusus } \\
\text { Menjurus } \\
\text { kepada } \\
\text { Pelanggaran }\end{array}$ & $\begin{array}{l}6 \\
2 \\
8\end{array}$ & $\begin{array}{r}20 \\
6,7 \\
26,6\end{array}$ \\
\hline 3 & Pedagang & 1) & $\begin{array}{l}\text { Kenakalan } \\
\text { Biasa } \\
\text { Kenakalan } \\
\text { Khusus } \\
\text { Menjurus } \\
\text { kepada } \\
\text { Pelanggaran } \\
\end{array}$ & $\begin{array}{l}3 \\
2 \\
-\end{array}$ & $\begin{array}{c}10 \\
6,7 \\
-\end{array}$ \\
\hline 4 & Buruh & 1) & $\begin{array}{l}\text { Kenakalan } \\
\text { Biasa } \\
\text { Kenakalan } \\
\text { Khusus } \\
\text { Menjurus } \\
\text { kepada } \\
\text { Pelanggaran }\end{array}$ & $\begin{array}{l}2 \\
- \\
-\end{array}$ & $\begin{array}{c}- \\
6,7 \\
-\end{array}$ \\
\hline
\end{tabular}

Sumber: Data yang diolah

Remaja sebagai pelajar dan tidak bekerja (menganggur) masing-masing terdapat 13 orang atau 43,3\% dari jumlah remaja, sebagai buruh dan pedagang masing-masing 2 remaja atau $6,7 \%$.

Berdasarkan hasil perhitungan bahwa pelajar yang melakukan kenakalan biasa terdapat lima remaja atau $16,7 \%$, kenakalan yang menjurus pada pelanggaran dan kejahatan dua remaja atau $6,7 \%$, dan kenakalan khusus ada enam

\section{Jurnal Sociopolitico}


remaja atau 20\%. Sedangkan mereka yang tidak bekerja atau menganggur, semuanya ada 13 orang yang melakukan kenakalan khusus, juga mereka yang bekerja sebagai pedagang dan buruh semuanya pernah melakukan kenakalan khusus.

Dengan demikian, dapat disimpulkan bahwa kecenderungan untuk melakukan kenakalan khusus ataupun jenis kenakalan lainnya adalah remaja yang tidak sibuk atau banyak waktu luang yang tidak dimanfaatkan untuk kegiatan positif. Sedangkan remaja yang memiliki pekerjaan atau sekolah kemungkinan kecil untuk melakukan kenakalan khusus atau kenakalan lainnya.

Pada umumnya, kegiatan atau pekerjaan di masa remaja sering hanya berkisar pada kegiatan sekolah dan seputar usaha menyelesaikan urusan di rumah, selain itu mereka bebas, tidak ada kegiatan lainnya. Apabila waktu luang tanpa kegiatan ini terlalu banyak, pada si remaja akan menimbulkan gagasan untuk mengisi waktu luangnya dengan berbagai bentuk kegiatan. Apabila si remaja melakukan kegiatan yang positif, hal ini tidak akan menimbulkan masalah. Namun, jika ia melakukan kegiatan yang negatif, maka lingkungan dapat terganggu. Sering kali perbuatan negatif ini hanya terdorong rasa iseng saja. Sebagaimana yang diungkapkan oleh Bapak Sumardi berikut:

Bahwa:Tindakan iseng ini, selain untuk mengisi waktu juga tidak jarang dipergunakan para remaja untuk menarik perhatian lingkungannya. Perhatian yang diharapkan dapat berasal dari orangtuanya maupun kawan sepermainannya. Celakanya, kawan sebaya sering menganggap iseng berbahaya adalah salah satu bentuk pamer sifat jagoan yang sangat membanggakan. Misalnya, ngebut tanpa lampu dimalam hari, mencuri, merusak, minum minuman keras, obat bius, dan sebagainya. Munculnya kegiatan iseng tersebut selain atas inisiatif si remaja sendiri, sering pula karena dorongan teman sepergaulan yang kurang sesuai. Sebab dalam masyarakat, pada umunya apabila seseorang tidak mengikuti gaya hidup anggota kelompoknya maka ia akan dijauhi oleh lingkungannya. Tindakan pengasingan ini jelas tidak mengenakkan hati si remaja, akhirnya mereka terpaksa mengikuti tindakan kawankawannya. Akhirnya ia terjerumus.

Berdasarkan pendapat tersebut ada kemungkinan, keisengan remaja adalah semacam 'refreshing' atas kejenuhannya dengan urusan tugas-tugas sekolah. Dan apabila anak senang berkelahi, orangtua dapat memberikan penyaluran dengan mengikutkannya pada satu kelompok olahraga beladiri.

Mengisi waktu luang selain diserahkan kepada kebijaksanaan remaja, ada baiknya pula orangtua ikut memikirkannya pula. Orangtua hendaknya jangan hanya tersita oleh kesibukan seharihari. Orangtua hendaknya tidak hanya memenuhi kebutuhan materi remaja saja. Orangtua hendaknya juga memperhatikan perkembangan batinnya. Remaja, selain membutuhkan materi, sebenarnya juga membutuhkan perhatian dan kasih sayang. Oleh karena itu, waktu luang yang dimiliki remaja dapat diisi dengan kegiatan keluarga sekaligus sebagai sarana rekreasi. Kegiatan keluarga ini hendaknya dapat diikuti oleh seluruh anggota keluarga.

\section{Jurnal Sociopolitico}


Kegiatan keluarga dapat pula berupa tukar pikiran dan berbicara dari hati ke hati. Misalnya, dengan makan malam bersama atau duduk santai di ruang keluarga.

\section{3) Hubungan antara tingkat pendidikan dengan tingkat kenakalan yang dilakukan \\ Memberikan pendidikan yang} sesuai adalah merupakan salah satu tugas orang tua kepada anak. Agar anak dapat memperoleh pendidikan yang sesuai dengan memilihkan sekolah yang bermutu. Selain itu, perlu dipikirkan pula latar belakang agama pengelola sekolah. Hal ini penting untuk menjaga agar pendidikan Agama yang telah diperoleh anak di rumah tidak kacau dengan agama yang diajarkan di sekolah.

Orangtua juga hendaknya membantu memberikan pengarahan agar masa depan si anak berbahagia. Orang tua juga tidak memaksakan kehendaknya agar di masa depan anaknya memilih profesi tertentu yang sesuai dengan keinginan orangtua. Pemaksaan ini tidak jarang justru akan berakhir dengan kekecewaan. Sebab, meski memang ada sebagian anak yang berhasil mengikuti kehendak orangtuanya tersebut, tetapi tidak sedikit pula yang kurang berhasil dan kemudian menjadi kecewa, frustrasi dan akhirnya tidak ingin bersekolah sama sekali. Mereka malah pergi bersama dengan kawan-kawannya, bersenang-senang tanpa mengenal waktu bahkan mungkin kemudian menjadi salah satu remaja yang suka melakukan kenakalan, sebagai pengguna obat-obat terlarang, minumminuman keras dan sebagainya.

Oleh karena itulah, seharusnya semakin tinggi tingkat pendidikan akan semakin rendah melakukan kenakalan. Sebab dengan pendidikan yang semakin

\section{Jurnal Sociopolitico}

Fakultas Ilmu Sosial dan Ilmu Politik tinggi, nalar seseorang semakin baik. Artinya mereka tahu aturan-aturan ataupun norma sosial mana yang seharusnya tidak boleh dilanggar atau setidaknya mereka tahu rambu-rambu mana yang harus dihindari dan mana yang harus dikerjakan. Tetapi dalam kenyataannya tidak demikian. Sebagaimana keterangan dalam tabel berikut ini:

Tabel 4

Jumlah tingkat Pendidikan Remaja dengan Bentuk Kenakalan

\begin{tabular}{|c|c|c|c|c|c|}
\hline No & $\begin{array}{c}\text { Tingkat } \\
\text { Pendidikan }\end{array}$ & & $\begin{array}{l}\text { Bentuk } \\
\text { Kenakalan }\end{array}$ & $\mathbf{F}$ & $\%$ \\
\hline 1 & SD & $\begin{array}{l}\text { 1) } \\
\text { 2) } \\
\text { 3) }\end{array}$ & $\begin{array}{l}\text { Kenakalan } \\
\text { Biasa } \\
\text { Kenakalan } \\
\text { Khusus } \\
\text { Menjurus } \\
\text { kepada } \\
\text { Pelanggaran }\end{array}$ & $\begin{array}{l}- \\
1 \\
-\end{array}$ & $\begin{array}{c}- \\
3,3 \\
-\end{array}$ \\
\hline 2 & SLTP & $\begin{array}{l}\text { 1) } \\
\text { 2) } \\
\text { 3) }\end{array}$ & $\begin{array}{l}\text { Kenakalan } \\
\text { Biasa } \\
\text { Kenakalan } \\
\text { Khusus } \\
\text { Menjurus } \\
\text { kepada } \\
\text { Pelanggaran }\end{array}$ & $\begin{array}{c} \\
11 \\
1\end{array}$ & $\begin{array}{c}- \\
36,7 \\
3,3\end{array}$ \\
\hline 3 & SMA & $\begin{array}{l}\text { 1) } \\
\text { 2) } \\
\text { 3) }\end{array}$ & $\begin{array}{l}\text { Kenakalan } \\
\text { Biasa } \\
\text { Kenakalan } \\
\text { Khusus } \\
\text { Menjurus } \\
\text { kepada } \\
\text { Pelanggaran }\end{array}$ & $\begin{array}{c}4 \\
1 \\
12\end{array}$ & $\begin{array}{c}13,3 \\
3,3 \\
40\end{array}$ \\
\hline & Jumlah & & & $\mathrm{N}=30$ & $100=\%$ \\
\hline
\end{tabular}

Sumber: Data yang diolah

Berdasarkan tabel di atas dapat diketahui bahwa Remaja Mekar Jaya yang menyandang tamatan atau lulusan SLTA justru yang paling banyak melakukan tindak kenakalan yakni tedapat 17 remaja atau $56,1 \%$ nya, artinya ada separuh lebih remaja yang statusnya berpendidikan. Adapun kenakalan yang mereka lakukan terdapat 12 remaja atau $40 \%$ melakukan kenakalan khusus, 1 remaja atau 3,3\% melakukan kenakalan yang menjurus pada pelanggaran dan kejahatan, dan empat remaja atau $13,3 \%$ nya melakukan kenakalan biasa. Demikian juga mereka 
yang berpendidikan terakhirnya di SLTP, dari 12 remaja, 11 remaja atau $36,7 \%$ melakukan kenakalan khusus. Sedang mereka yang hanya tamat SD, ada satu remaja yang melakukan kenakalan khusus.

Dengan demikian, maka tidak ada hubungan antara tingkatan pendidikan dengan kenakalan yang dilakukan, artinya semakin tinggi pendidikannya tidak bisa dijamin untuk tidak melakukan kenakalan. Artinya di lokasi penelitian kenakalan remaja yang dilakukan bukan karena rendahnya tingkat pendidikan mereka, namun karena di semua tingkat pendidikan dari SD sampai dengan SLTA proporsi untuk melakukan kenakalan sama kesempatannya. Dengan demikian faktor yang kuat adalah seperti yang disebutkan di atas, yaitu adanya waktu luang yang tidak dimanfaatkan untuk kegiatan positif, dan adanya pengaruh buruk dalam sosialisasi dengan teman-teman bermainnya atau karena faktor lingkungan sosial perkotaan yang besar pengaruhnya.

Hal ini, dibenarkan oleh Bapak Yasmo Rejo, selaku Ketua RW II, mengatakan:

Bahwa di kalangan remaja, memiliki banyak kawan adalah merupakan satu bentuk prestasi tersendiri. Makin banyak kawan, makin tinggi nilai mereka di mata teman-temannya. Apalagi mereka dapat memiliki teman dari kalangan terbatas. Misalnya, anak orang yang paling kaya di kota itu, anak pejabat pemerintah setempat bahkan mungkin pusat atau pun anak orang terpandang lainnya. Di jaman sekarang, pengaruh kawan bermain ini bukan hanya membanggakan si remaja saja tetapi bahkan juga pada orang tuanya. Orangtua juga senang dan bangga kalau anaknya mempunyai teman bergaul dari kalangan tertentu tersebut. Padahal, kebanggaan ini adalah semu sifatnya. Malah kalau tidak dapat dikendalikan, pergaulan itu akan menimbulkan kekecewaan nantinya. Sebab kawan dari kalangan tertentu pasti juga mempunyai gaya hidup yang tertentu pula. Apabila si anak akan berusaha mengikuti tetapi tidak mempunyai modal ataupun orangtua tidak mampu memenuhinya maka anak akan menjadi frustrasi. Apabila timbul frustrasi, maka remaja kemudian akan melarikan rasa kekecewaannya itu pada narkotik, obat terlarang, dan lain sebagainya.Pengaruh kawan ini memang cukup besar.

\section{4) Hubungan Kenakalan Remaja dengan Keberfungsi Sosial Keluarga}

Dalam kerangka konsep telah diuraikan tentang keberfungsian sosial keluarga diantaranya adalah kemampuan fungsi sosial secara positif dan adaptif bagi keluarga yaitu jika berhasil dalam melaksanakan tugas-tugas kehidupan peranan, dan fungsinya serta mampu memenuhi kebutuhannya.

\section{5) Hubungan antara pekerjaan orang tuanya dengan tingkat kenakalan Remaja}

Untuk mengetahui apakah kenakalan juga ada hubungannya dengan pekerjaan orangtuanya, artinya untuk tingkat pemenuhan kebutuhan hidup. Karena pekerjaan orangtua dapat dijadikan ukuran kemampuan ekonomi, guna memenuhi kebutuhan keluarganya. Hal ini perlu diketahui karena dalam keberfungsian sosial, salah satunya adalah bahwa orang tua harus mampu memenuhi kebutuhannya.

\section{Jurnal Sociopolitico}


Orangtua hendaknya memberikan teladan untuk menanamkan pengertian bahwa 'uang' hanya dapat diperoleh dengan kerja dan keringat. Remaja hendaknya dididik agar dapat menghargai nilai uang. Mereka dilatih agar mempunyai sifat tidak suka memboroskan uang tetapi juga tidak terlalu kikir. Anak diajarkan hidup dengan bijaksana dalam mempergunakan uang dengan selalu menggunakan prinsip hidup 'Jalan tengah'.

Demikian penuturan Bapak Yasmo Rejo berikut: Pemberian uang saku kepada remaja memang tidak dapat dihindarkan. Namun, sebaiknya uang saku diberikan dengan dasar kebijaksanaan. Jangan berlebihan. Uang saku yang diberikan dengan tidakbijaksana akan dapat menimbulkan masalah., seperti menjadi boros, tidak menghargai uang, dan anak malas belajar, sebab mereka pikir tanpa kepandaian pun uang gampang. ${ }^{1}$

Berikut ini akan diuraikan tabel pekerjaan orang tua remaja atau remaja, yakni:

Tabel 5

Jenis Pekerjaan Orang Tua dengan Tingkat Kenakalan Remaja

\begin{tabular}{|c|l|c|c|}
\hline No & $\begin{array}{c}\text { Jenis Pekerjaan Orang } \\
\text { Tua }\end{array}$ & F & \% \\
\hline $\mathbf{1}$ & Pegawai negeri & 5 & 16,6 \\
\hline $\mathbf{2}$ & Pedagang & 4 & 13,3 \\
\hline $\mathbf{3}$ & Buruh & 5 & 16,6 \\
\hline $\mathbf{4}$ & Tukang kayu & 2 & 6,7 \\
\hline $\mathbf{5}$ & Montir/ sopir & 6 & 20 \\
\hline $\mathbf{6}$ & Pensiunan & 1 & 3,3 \\
\hline $\mathbf{7}$ & Wiraswasta & 5 & 16,6 \\
\hline & Jumlah & $\mathbf{N = - 3 0}$ & $\mathbf{1 0 0 =} \%$ \\
\hline
\end{tabular}

Sumber: Data yang diolah

Berdasarkan data yang ada, remaja yang pekerjaan oangtuanya sebagai pegawai negeri ada lima remaja atau $16,6 \%$ dari jumlah keseluruhan, sebagai

${ }^{1}$ Wawancara dengan Bapak Yasmo Rejo, selaku Ketua RW II, Mekar Jaya, pada tanggal 7 Januari 2020 pedagang ada empat remaja atau $13,3 \%$, buruh lima remaja atau $16,6 \%$, tukang kayu dua remaja atau $6,7 \%$, montir/ sopir enam remaja atau $20 \%$, wiraswasta ada lima remaja atau $16,6 \%$, dan pensiunan satu remaja atau $3,3 \%$ nya.

Dengan melihat tabel uraian di atas, dapat diketahui bahwa kecenderungan anak pegawai negeri walaupun melakukan kenakalan, namun hanya pada tingkat kenakalan biasa. Lain halnya bagi mereka yang orang tuanya mempunyai pekerjaan dagang, buruh, montir/ sopir, dan wiraswasta yang kecenderungannya melakukan. kenakalan khusus. Hal ini berarti pekerjaan orang tua berhubungan dengan tingkat kenakalan yang dilakukan oleh anak-anaknya. Keadaan yang demikian, karena mungkin bagi pegawai negeri lebih memperhatikan anaknya untuk mencapai masa depan yang lebih ataupun kedisiplinan yang diterapkan serta nilai-nilai yang disosisalisasikan lebih efektif. Sedang bagi mereka yang bukan pegawai negeri hanya sibuk mencari nafkah untuk memenuhi kebutuhan keluarganya, sehingga kurang ada perhatian pada sosialisasai penanaman nilai dan norma-norma sosial kepada anakanaknya. Akibat dari semua itu, maka anak-anaknya lebih tersosisalisasi oleh kelompoknya yang kurang mengarahkan pada kehidupan yang normatif.

\section{6) Hubungan antara Keutuhan Keluarga dengan Tingkat Kenakalan}

Secara teoritis keutuhan keluarga dapat berpengaruh terhadap kenakaIan remaja. Artinya banyak terdapat anak-anak remaja yang nakal datang dari keluarga yang tidak utuh (broken home), baik dilihat dari struktur keluarga maupun dalam interaksinya di keluarga.

\section{Jurnal Sociopolitico}


Keluarga yang broken home bisa digambarkan seperti orangtua yang berpisah, seperti bercerai atau terjadi 'perang dingin' dalam keluarga. Pada masa remaja terutama remaja awal merupakan fase di mana teman sebaya sangat penting baginya. Pada periode ini juga sering terbentuk kelompok atau lebih dikenal dengan sebutan gang. Idealisme mereka sangat kuat dan identitas diri mulai terbentuk dengan emosi yang labil. Dalam fase ini, orangtua sangat berperan dalam mengawasi anak-anaknya dalam bergaul dan menuntun mereka dalam menjalani hidup supaya tidak salah bergaul dengan teman-teman yang dapat menjerumuskan mereka. Keluarga bagaikan vital mereka sebagai pedoman dalam hidup. Bila remaja kehilangan pedoman hidup ini, maka mereka akan susah untuk melewati masa kritis dalam hidupnya. Masa kritis tersebut diwarnai oleh konflik-konflik internal, pemikiran kritis, perasaan mudah tersinggung, dan cita-cita serta keinginan yang tinggi, tetapi sulit untuk diwujudkan sehingga menimbulkan 'stress' dan 'frustasi'. Masalah keluarga yang broken home ini menjadi akar dari permasalahan anak-anak. Keluarga merupakan dunia keakraban dan di dalamnya terdapat tali batin yang merupakan vital dalam hidup. Berikut ini akan diuraikan kutuhan struktur keluarga dalam berinteraksi, sebagaimana yang terdapat dalam tabel berikut ini:

\section{Tabel 6}

\section{Keutuhan Struktur Keluarga dalam}

\section{Berinteraksi}

\begin{tabular}{|c|l|c|c|}
\hline No & $\begin{array}{c}\text { Keutuhan Struktur } \\
\text { Keluarga } \\
\text { dalam Berinteraksi }\end{array}$ & Jumlah & \% \\
\hline $\mathbf{1}$ & Keluarga yang utuh & $\mathbf{2 1}$ & $\mathbf{7 0}$ \\
\hline $\mathbf{2}$ & Keluarga tidak utuh & $\mathbf{9}$ & $\mathbf{3 0}$ \\
\hline & Jumlah & $\mathbf{N}=-\mathbf{3 0}$ & $\mathbf{1 0 0 =}$ \\
\hline
\end{tabular}

Sumber: Data yang Diolah
Dilihat dari keutuhan struktur keluarga, 21 remaja atau $70 \%$ dari keluarga utuh, dan sembilan remaja dari keluarga tidak utuh. Berdasarkan data pada tabel di atas dan dihubungkan dengan struktur keluarga, ternyata struktur keluarga yang utuh dan tidak bukan merupakan jaminan bagi anaknya untuk melakukan kenakalan, terutama kenakalan khusus. Karena ternyata mereka yang berasal dari keluarga utuh justru lebih banyak yang melakukan kenakalan khusus.

Namun, jika dilihat dari keutuhan dalam interaksi, terlihat jelas bahwa mereka yang melakukan kenakalan khusus berasal dari keluarga yang interaksinya kurang dan tidak serasi atau sebesar $76,6 \%$. Perlu diketahui bahwa keluarga yang interaksinya serasi berjumlah tiga remaja atau $10 \%$ nya, sedangkan yang interaksinya kurang serasi ada 14 remaja atau $46,7 \%$, dan yang tidak serasi 13 remaja atau 43,3\%. Jadi ketidakberfungsian keluarga untuk menciptakan keserasian dalam interaksi mempunyai kecenderungan anak remajanya melakukan kenakalan. Artinya semakin tidak serasi hubungan atau interaksi dalam keluarga tersebut tingkat kenakalan yang dilakukan semakin berat, yaitu pada kenakalan khusus.

\section{7) Hubungan antara kehidupan beragama keluarganya dengan tingkat kenakalan}

Sebagaimana telah dijelaskan pada bab sebelumnya, bahwa keluarga merupakan media yang utama untuk mewariskan nilai-nilai dan norma-norma agama. Ayah dan Ibu sebagai unsur pokok sangat berpengaruh dan menetukan pada perkembangan anak-anaknya. Begitupun dalam pembinaan keberagamaan dan

\section{Jurnal Sociopolitico}


pengamalan terhadap agama pada masa remaja. Orang tua (keluarga) dalam hal ini menempati posisi yang sangat menentukan terutama dari sikap dan perilaku orang tua si remaja.

Kehidupan beragama keluarga juga dijadikan salah satu ukuran untuk melihat keberfungsian sosial keluarga. Sebab dalam konsep keberfungsian. juga dilihat dari segi rohani. Bagi keluarga yang menjalankan kewajiban agama secara baik, berarti mereka akan menanamkan nilai-nilai dan norma yang baik. Artinya secara teoritis bagi keluarga yang menjalankan kewajiban agamanya socara baik, maka anak-anaknyapun akan melakukan hal-hal yang baik sesuai dengan norma agama. Sebagaimana dalam tabel berikut ini:

\section{Tabel 7}

Keluarga dengan Ketaatan dalam Beragama

\begin{tabular}{|c|l|c|c|}
\hline No. & \multicolumn{1}{|c|}{$\begin{array}{c}\text { Ketaatan dalam } \\
\text { beragama }\end{array}$} & Jumlah & $\mathbf{\%}$ \\
\hline $\mathbf{1}$ & Keluarga yang taat & $\mathbf{6}$ & $\mathbf{2 0}$ \\
\hline $\mathbf{2}$ & $\begin{array}{l}\text { Keluarga yang } \\
\text { kurang taat }\end{array}$ & $\mathbf{1 5}$ & $\mathbf{5 0}$ \\
\hline $\mathbf{3}$ & $\begin{array}{l}\text { Keluarga yang tidak } \\
\text { taat }\end{array}$ & $\mathbf{9}$ & $\mathbf{3 0}$ \\
\hline & Jumlah & $\mathbf{N}=\mathbf{- 3 0}$ & $\mathbf{1 0 0}=\%$ \\
\hline
\end{tabular}

Sumber: Data yang Diolah

Berdasarkan data yang ada mereka yang keluarganya taat beragama 6 remaja atau ada 20\%, sedangkan kurang taat beragama 15 remaja atau $50 \%$ nya, dan tidak taat beragama 9 remaja atau $30 \%$. Berdasarkan tabel korelasinya dapat diketahui bahwa $70 \%$ dari remaja yang keluarganya kurang dan tidak taat beragama melakukan kenakalan khusus.

Dengan demikian ketaatan dan tidaknya beragama bagi keluarga sangat berhubungan dengan kenakalan yang dilakukan oleh anak-anaknya. Hal ini berarti bahwa bagi keluarga yang taat menjalankan kewajiban agamanya kecil kemungkinan anaknya melakukan kenakalan, baik kenakalan yang menjurus pada pelanggaran dan kejahatan maupun kenakalan khusus, demikian juga sebaliknya.

\section{8) Hubungan antara sikap orang tua dalam pendidikan anaknya dengan tingkat kenakalan}

Banyak ragam dari orang tua, cara mendidik anak-anaknya. Hal inipun dapat menjadi salah satu sebab kenakalan yang disebutkan pada kerangka konsep di atas adalah sikap orang tua dalam mendidik atau mengasuh anaknya. Untuk lebih jelasnya lihat tabel berikut:

Tabel 8

Sistem Pendidikan Orang Tua Terhadap Anaknya

\begin{tabular}{|c|l|c|c|}
\hline No. & \multicolumn{1}{|c|}{$\begin{array}{c}\text { Sistem Pendidikan } \\
\text { Orang Tua }\end{array}$} & Jumlah & \% \\
\hline $\mathbf{1}$ & Otoriter & $\mathbf{5}$ & $\mathbf{1 6 , 7}$ \\
\hline $\mathbf{2}$ & Over protektif & $\mathbf{3}$ & $\mathbf{1 0}$ \\
\hline $\mathbf{3}$ & Kurang memperhatikan & $\mathbf{1 2}$ & $\mathbf{4 0}$ \\
\hline $\mathbf{4}$ & Tidak memperhatikan & $\mathbf{1 0}$ & $\mathbf{3 3 , 3}$ \\
\hline & Jumlah & $\mathbf{N = - 3 0}$ & $\mathbf{1 0 0 = \%}$ \\
\hline
\end{tabular}

Sumber: Data yang diolah

Mereka yang orang tuanya otoriter sebanyak 5 remaja $(16,6 \%)$, overprotection tiga remaja (10\%), orang tua yang kurang memperhatikan ada 12 remaja $(40 \%)$, dan orang tua yang tidak memperhatikan sama sekali ada 10 remaja" $(33,4 \%)$. Dari tabel tersebut dapat diketahui hubungan korelasi dari seluruh remaja yang orang tuanya tidak memperhatikan sama sekali anaknya melakukan kenakalan khusus, dan orang tua yang kurang memperhatikan anaknya ada 11 dari 12 remaja yang melakukan kenakalan khusus. Dari kenyataan tersebut ternyata peranan keluarga dalam pendidikan atau pola asuh orang tua sangat besar pengaruhnya terhadap kehidupan anak-anaknya, terutama dalam berinteraksi dengan lingkungan tempat tinggalnya.

\section{Jurnal Sociopolitico}




\section{9) Hubungan antara interaksi keluarga dengan lingkungannya dengan tingkat kenakalan}

Keluarga merupakan unit terkecil dalam masyarakat, oleh karena itu mau tidak mau harus berhubungan dengan lingkungan sosialnya. Adapun yang diharapkan dari hubungan tersebut adalah serasi, karena keserasian akan menciptakan kenyamanan dan ketenteraman dalam keluarga. Apabila hal itu dapat diciptakan oleh seluruh anggota keluarga, hal itu merupakan proses sosialisasi yang baik bagi anak anaknya. Keluarga yang dapat berhubungan serasi atau dapat beradaptasi dengan baik pada lingkungan sosialnya berjumlah 8 remaja atau $26,6 \%$, sedangkan yang kurang serasi atau kurang dapat beradaptasi berjumlah 12 remaja atau $40 \%$, dan sementara yang tidak serasi atau tidak dapat sama sekali berinteraksi dengan lingkungannya berjumlah 10 remaja atau $33,4 \%$.

Oleh karena itu, berdasarkan data yang ada terlihat bagi keluarga yang kurang dan tidak serasi hubungannya dengan tetangga atau lingkungan sosialnya mempunyai kecenderungan anaknya melakukan kenakalan pada tingkat yang lebih berat yaitu kenakalan khusus. Keadaan tersebut dapat dilihat dari 23 remaja yang melakukan kenakalan khusus, 19 remaja di antaranya berasal dari dari keluarga yang interaksinya dengan tetangga kurang atau tidak serasi.

10) Pernah tidaknya remaja ditahan dan dihukum hubungannya dengan keutuhan struktur dan interaksi keluarga, serta ketaatan keluarga dalam menjalankan kewajiban beragama
Ketua RW II Mekar Jaya, Bapak Yasmo Rejo, pada bahwa remaja yang pernah dipenjara data yang diperoleh dari Kantor Rukun Warga Mekar Jaya bahwa warganya atau remaja yang pernah ditahan atau dipenjara tentang remaja Mekar Jaya yang pernah ditahan berjumlah 15 orang, dari jumlah tersebut dua remaja atau $20 \%$ karena kasus perkelahian, masing-masing satu remaja atau 6,7\% karena kasus pengeroyokan dan pembunuhan, lima remaja $(33,3 \%)$ karena kasus obat terlarang (narkotika) dan delapan remaja atau 53,3\% karena kasus pencurian. ${ }^{2}$

Sedangkan remaja yang pernah dihukum penjara berjumlah 10 remaja dengan rincian tujuh remaja karena kasus pencurian, masing-masing satu remaja karena kasus pengeroyokan, pembunuhan, dan narkotika. Adapun lamanya mereka dihukum paling sedikit satu bulan dan paling lama tiga tahun, dengan rincian yaitu bahwa ada empat remaja atau $40 \%$ dihukum penjara selama satu bulan, tiga remaja atau 30\% dihukum tiga bulan, masing-masing satu remaja atau 10\% dihukum tujuh bulan, dua tahun, dan tiga tahun.

Berdasarkan data yang diperoleh bahwa remaja yang pernah ditahan dan di hukum semuanya dari keluarga yang struktur keluarganya utuh, tetapi interaksinya kurang dan tidak serasi. Hal ini menunjukkan bahwa masalah interaksi dalam keluarga merupakan sebab utama seorang remaja sampai ditahan dan dihukum penjara. Sedangkan dari sudut ketaatan dalam menjalankan kewajiban agama bagi keluarganya masih terdapat satu remaja yang pernah ditahan dan dihukum karena kasus pencurian. Artinya

${ }^{2}$ Wawancara dengan Bapak Yasmo Rejo, selaku Ketua RW II, Mekar Jaya, pada tanggal 7 Januari 2020 
bahwa ketaatan beragama dari keluarganya belum menjamin anaknya bebas dari kenakalan dan tidak pernah ditahan serta dihukum.

\section{Kesimpulan}

1. Bahwa bentuk-bentuk kenakalan remaja Mekar Jaya sebagaimana yang telah disebutkan dalam konsep teori, yaitu terdapat tiga bentuk kenakalan: a) Kenakalan biasa, seperti berbohong, begadang, pergi keluar rumah tanpa pamit, keluyuran, membolos sekolah, berkelahi dengan teman dan sebagainya; b) kenakalan yang menjurus pada pelanggaran dan kejahatan, seperti mengendarai kendaraan bermotor tanpa SIM, kebutkebutan/ mengebut, minum-minuman keras, mencuri, mencopet, berjudi dan menodong; dan c) kenakalan khusus, seperti menyalahgunakan narkotika, kumpul kebo, hubungan sex di luar nikah, menggugurkan kandungan, memperkosa, membunuh, melihat, membaca dan menonton gambargambar porno dan sebagainya.

2. Berdasarkan hasil wawancara dan analisis yang telah dilakukan dapat diketahui bahwa ada hubungan negatif antara keberfungsian sosial keluargannya dengan kenakalan remaja di Mekar Jaya Kecamatan Parenggean. Identitas remaja, baik sebagai pelajar ataupun pekerja samasama mempunyai kesempatan untuk melakukan kenakalan, baik itu kenakalan biasa, kenakalan khusus maupun kenakalan yang menjurus pada pelanggaran dan kejahatan. Remaja yang memiliki waktu luang banyak seperti mereka yang tidak bekerja atau menganggur dan masih pelajar kemungkinannya lebih besar untuk melakukan kenakalan atau perilaku menyimpang. Demikian juga dengan keberfungsian sosial keluarga, bahwa keluarga yang nota bene-nya keluarga yang utuh pun tidak menjamin anak untuk tidak melakukan kenakalan, terlebih lagi keluarga yang tingkat keberfungsian sosialnya rendah, maka kemungkinan besar anaknya akan melakukan kenakalan pada tingkat yang lebih berat. Sebaliknya bagi keluarga yang tingkat keberfungsian sosialnya tinggi, maka kemungkinan anak-anaknya melakukan kenakalan sangat kecil, apalagi kenakalan khusus. Oleh karena itulah pada umumnya bahwa ada hubungan negatif antara keberfungsian sosial keluarga dengan kenakalan remaja, artinya bahwa semakin tinggi keberfungsian sosial keluarga akan semakin rendah kenakalan yang dilakukan oleh remaja. Sebaliknya semakin ketidak berfungsian sosial suatu keluarga, maka semakin tinggi tingkat kenakalan remajanya (perilaku menyimpang yang dilakukan oleh remaja).

\section{Referensi}

Achlis, 1992. Praktek Pekerjaan Sosial 1, Bandung: STKS.

Ahmadi, Abu, 1997. Ilmu Sosial Dasar, Jakarta: Rineka Cipta.

Bertran, Alvin L, 1980. Sosiologi: Kerangka Acuan, Metode Penelitian, Teori-Teori tentang Sosialisasi, Kepribadian dan Kebudayaan, Terj. Sanapiah S Faisal, Surabaya: Bina Ilmu.

Black, James A., dan Dean J. Champion, 2001. Metode dan Masalah 
Penelitian Sosial, Terj. E. Koswara et.all., Bandung: Refika Aditama.

Buku pedoman 8 Bakolak Inpres No: 6 / 1977.

Daradjat, Zakiah, 1982. Kesehatan Mental, Jakarta: Gunung Agung.

Darmansyah, 1986. Ilmu Sosial Dasar, Surabaya: Usaha Nasional.

Departemen Agama RI, 1989. Al-Qur'an dan Terjemahnya, Semarang: Toha Putra.

Dokumentasi ParenggeanKelurahan Ngupasan Kecamatan Gondomanan

Durkheim, Emile. 1992. Elementary Forms of the Religious Life, terj. Inyak Ridwan Muzir, New York: Free Press.

Eitzen, Stanlen D., 1986. Social Problems, Boston, Sydney, Toronto: Allyn and Bacon inc.

Goode, William L, 1983. Sosiologi Keluarga, Terj. Lailahanourn Hasyim, Jakarta: Bina Aksara.

Gumarso, Singgih D. et.al., 1988. Psikologi Remaja, Jakarta: BPK Gunung Mulya.

Hadi, Sutrisno, 1990. Metodologi Research II, Yogyakarta: Yayasan Penerbit Fakultas Psikologi UGM.

lchwan, Nur, 1998. Pelaksanaan Pembinaan dan Penyuluhan dalam Menangani Siswa yang Bermasalah di SMU Muhammadiyah 1 Sukoharjo tahun 1997-1998, dalam Skripsi: Fakultas Dakwah IAIN Sunan Kalijaga Yogyakarta.

Kartono, Kartini, 1988. Psikologi Sosial 2, Kenakalan Remaja, Jakarta. Rajawali.

Kauffman, James, M., 1989. Characteristics of Behaviour Disorders of Children and Youth, Columbus, London, Toronto: Merril Publishing Company.
Miles, Matthew B., dan A. Michael Huberman, 1992. Analisis Data Kualitatif, Terj. Tjeptjep Rohendi Rohidi, Jakarta: UI Press.

Monografi Kelurahan Ngupasan Kecamatan Gondomanan Tahun 2007

Nafisah, Ety Durratun, 2002. Bentukbentuk Kenakalan Santri dan Upaya Mengatasinya di Pondok Pesantren Al-Muayyad Surakarta, dalam Skripsi: Fakultas Tarbiyah IAIN Sunan Kalijaga Yogyakarta.

Nawawi, Hadari, 2003. Metodologi Penelitian Bidang Sosial, Yogyakarta: Gadjah Mada University Press, cet. X.

Romdhiyati, Tatik, 1997. Upaya BP dalam Meningkatkan Akhlak Siswa di Madrasah Wallimin Muhammadiyah Yogyakarta, dalam Skripsi: Fakultas Tarbiyah IAIN Sunan Kalijaga Yogyakarta.

Salim, Peter, 1991. Kamus Bahasa Indonesia Kontemporer, Jakarta, Modern EnglishPress,

Simanjuntak, B., 1984. Latar Belakang Kenakalan Remaja, Bandung: Alumni.

Singarimbun, Masri, dan Sofian Effendi, 1985. Metode Penelitian Survey, Jakarta: LP3S.

Soekanto, Soerjono, 1988. Sosiologi Penyimpangan, Jakarta: Rajawali Press.

Soekanto, Soerjono, 1988. Sosiologi Suatu Pengantar, Jakarta: Rajawali Press.

Soemardjan, Selo, 1964. Setangkai Bunga Sosiologi, Jakarta: Yayasan BPFEUI.

\section{Jurnal Sociopolitico}

